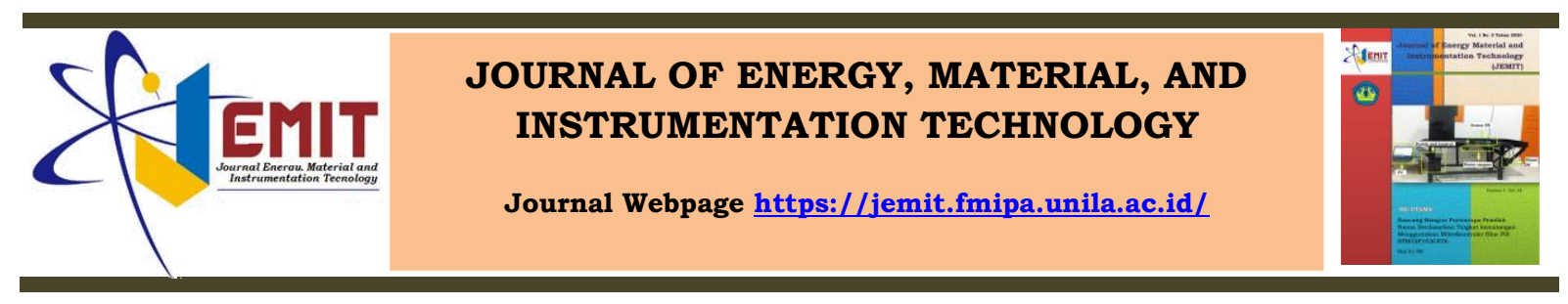

\title{
Rancang Bangun Purwarupa Pemilah Nanas Berdasarkan Tingkat Kematangan Menggunakan Mikrokontroler Blue Pill STM32F103C8T6
}

\author{
Friska Tiara Desya, Arif Surtonob ${ }^{\mathrm{b}}$, Amir Supriyantoc, dan Junaidid \\ Jurusan Fisika, Universitas Lampung, Bandar Lampung, Indonesia, 35141
}

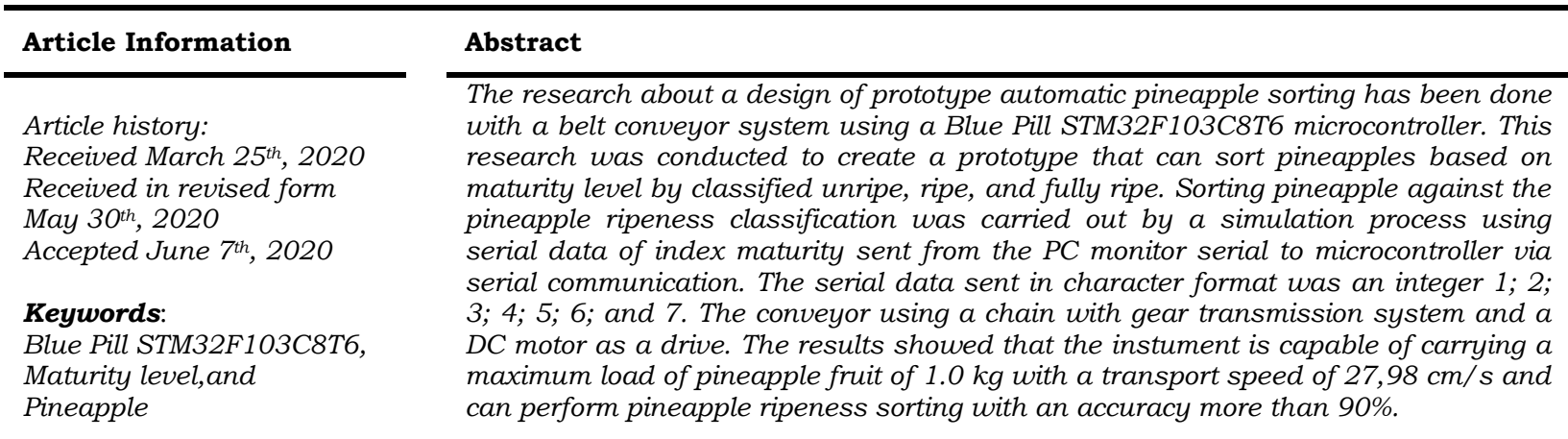

\begin{tabular}{ll}
\hline Informasi Artikel & Abstrak \\
\cline { 2 - 3 } & Telah dilakukan penelitian berupa rancang bangun purwarupa pemilah nanas \\
Proses artikel: & secara otomatis dengan sistem konveyor sabuk menggunakan mikrokontroler Blue \\
Diterima 25 Maret 2020 & Pill STM32F103C8T6. Purwarupa hasil rancangan yang dapat memilah nanas \\
Diterima dan direvisi dari & berdasarkan tingkat kematangan dengan klasifikasi nanas mentah, matang, dan \\
Accepted 7 Juni 2020 & sangat matang. Pemilahan nanas terhadap klasifikasi kematangan nanas \\
Kata kunci: & dilakukan dengan proses simulasi menggunakan data serial indeks kematangan \\
Blue Pill STM32F103C8T6, & yang dikirimkan dari PC ke mikrokontroler melalui komunikasi serial. Data \\
Indeks kematangan, dan & Konveyor pada alat ini menggunakan sistem transmisi rantai dan roda gigi serta \\
Nanas & menggunakan penggerak berupa motor DC. Hasil pengujian menunjukkan bahwa \\
& alat ini mampu mengangkut beban buah nanas maksimum sebesar 1,0 kg dengan \\
kecepatan pengangkutan sebesar 27,98 cm/s dan dapat melakukan pemilahan & kematangan nanas dengan akurasi lebih dari 90\%.
\end{tabular}

\section{Pendahuluan}

Sektor pertanian merupakan sektor yang mempunyai peranan strategis dalam struktur pembangunan perekonomian nasional, salah satunya adalah tanaman hortikultura (Kementerian Pertanian, 2015). Nanas merupakan salah satu komoditas unggulan tanaman hortikultura Indonesia yang telah dikenal di seluruh dunia dan masuk dalam lima besar produsen nanas dunia (Kementerian Pertanian, 2016). Menurut Badan Pusat Statistik (2017), produktivitas nanas di Indonesia menempati posisi keempat dunia dengan total produksi mencapai 1.795 .986 ton. Pencapaian produksi nanas terbesar di Indonesia banyak dihasilkan di provinsi Lampung dengan total produksi mencapai 633.095 ton. Produksi nanas nasional ini sebagian besar digunakan untuk keperluan ekspor.

* Corresponding author.

E-mail addres: (a)friskatiara01@gmail.com, (b)arif.surtono@fmipa.unila.ac.id, (b)amir.supriyanto@fmipa.unila.ac.id, (d)junaidi.1982@fmipa.unila.ac.id 
Dalam perdagangan internasional, kualitas nanas yang akan diekspor sangatlah penting. Pemantauan dan peningkatan kualitas nanas yang diperdagangkan merupakan suatu syarat dalam penanganan produk nanas. Salah satu cara untuk meningkatkan kualitas nanas adalah dengan melakukan pemilahan untuk menentukan klasifikasi kematangan nanas. Pada umumnya proses pemilahan di industri nanas masih dilakukan secara manual menggunakan tenaga manusia. Proses ini memiliki kekurangan yaitu rendahnya efisiensi, objektifitas, dan tingkat konsistensi. Sejalan dengan perkembangan teknologi saat ini, proses pemilahan banyak dikembangkan dengan sistem otomatisasi menggunakan perangkat elektronik dan mekanik untuk keefektifan serta keakuratan hasil yang didapat.

Untuk skala industri, alat pemilah buah yang banyak digunakan adalah pemilahan dengan sistem konveyor. Pemilahan dengan sistem konveyor di industri sangat efisien dalam proses pemindahan ataupun pengangkutan barang, baik barang yang sudah jadi maupun barang yang akan diproses di bagian lain (Tamam dkk., 2018). Alat pemilah otomatis buah nanas belum dikembangkan di Indonesia. PT Great Giant Pineapple (GGP) yang merupakan pelopor perusahaan produsen nanas pertama Indonesia melakukan proses pemilahan buah secara semi-otomatis yaitu hanya dilakukan pemilahan berdasarkan ukuran buah, sedangkan pemilahan kematangan nanas masih dilakukan secara manual berdasarkan pengamatan oleh pekerja terhadap warna kulit nanas.

Pemilahan nanas berdasarkan tingkat kematangan dibagi menjadi tujuh tingkat yang berbeda yaitu dari indeks 1 sampai 7 diukur berdasarkan warna kulit nanas (Shamsudin dkk., 2009). Ke tujuh indeks tersebut dikelompokkan menjadi tiga kematangan warna kulit nanas yaitu mentah, matang, dan sangat matang. Warna kulit nanas mentah ditandai dengan tingkat kematangan pada indeks 1 dan 2, warna kulit nanas matang ditandai dengan tingkat kematangan pada indeks 3, 4, dan 5, serta warna kulit nanas sangat matang ditandai dengan tingkat kematangan pada indeks 6 dan 7 (Bakar dkk., 2013).

Untuk mempermudah proses pemilahan tingkat kematangan nanas diperlukan suatu sistem intrumentasi yang dapat memilah nanas secara otomatis. Realisasi dari sistem ini berupa purwarupa pemilah nanas otomatis menggunakan sistem konveyor dengan pengontrol otomatis menggunakan mikrokontroler Blue Pill STM32F103C8T6 dan aktuator motor stepper sebagai pemilah nanas. Pemilahan nanas berdasarkan hasil klasifikasi tingkat kematangan yang dikirimkan oleh PC melalui port serial dalam format karakter berupa bilangan bulat 1, 2, 3, 4, 5, 6, dan 7 digunakan sebagai instruksi untuk menggerakkan motor stepper.

\section{Metode Penelitian}

Penelitian ini dilakukan dengan membuat perancangan sistem pemilah buah nanas terdiri atas sistem mekanik dan rangkaian elektronik untuk menjalankan purwarupa secara otomatis. Kemudian melakukan pengujian dan pengambilan data untuk mengetahui tingkat keberhasilan dari alat yang telah dibuat.

\subsection{Perancangan Sistem Mekanik}

Sistem mekanik purwarupa pemilah nanas dirancang menggunakan sistem konveyor sabuk. Perancangan sistem mekanik harus memperhitungkan parameter penggerak konveyor sabuk tersebut. Besar rasio roda gigi yang digunakan dapat ditentukan berdasarkan Persamaan 1 (Uicker dkk., 2016),

$$
R=\frac{\prod_{j=1}^{n} z_{2 j-1}}{\prod_{j=1}^{n} z_{2 j}}
$$

Besar roda gigi $R$ merupakan perbandingan antara perkalian jumlah gigi $z$ pada roda gigi penggerak dengan roda gigi yang digerakkan, dengan $j$ merupakan bilanga asli $(1,2,3, \ldots, n)$ dari pada roda gigi yang digunakan. Karena rasio roda gigi adalah perbandingan antara kecepatan putar masukan $N_{0}$ dengan kecepatan putar keluaran $N_{t}$ dalam satuan rotasi per menit (rpm), sehingga kecepatan putar keluaran motor dapat diperoleh dengan Persamaan 2:

$$
N_{t}=R N_{o}
$$


Desy F T, Surtono A, Supriyanto A, dan Junaidi, 2020, Rancang Purwarupa Pemilah Nanas Berdasarkan Tingkat Kematangan Menggunakan Mikrokontroler Blue Pill STM32F103C8T6, Jurnal of Energy, Material, and Instrumentation Technology, Vol. 1 No. 3, 2020

Daya motor $P$ yang dibutuhkan untuk menjalankan konveyor sabuk pada purwarupa pemilah nanas dapat ditentukan menggunakan Persamaan 3 (Khurmi dan Gupta, 2005):

$$
P=\frac{2 \pi N_{t} \tau}{60}
$$

di mana $P$ adalah daya motor penggerak (watt), $N_{t}$ adalah kecepatan putar keluaran motor (rpm), dan $\tau$ adalah torsi motor penggerak $(\mathrm{Nm})$. Kemudian, kecepatan konveyor sabuk dapat diperoleh menggunakan Persamaan 4:

$$
v_{r}=\frac{\pi d N_{t}}{60}
$$

dengan $v_{r}$ adalah kecepatan konveyor sabuk $(\mathrm{m} / \mathrm{s})$ dan $d$ adalah diameter rol penggerak sabuk $(\mathrm{m})$.

\subsection{Perangkat Keras Sistem Kontrol}

Perangkat terdiri dari sistem elektromekanis yang memiliki dua komponen utama untuk proses pemilahan nanas yaitu unit pengontrol dengan mikrokontroler Blue Pill STM31F103C8T6 dan aktuator menggunakan motor stepper, serta unit penggerak mekanik konveyor sabuk menggunakan motor DC. Komponen penyusun pada purwarupa ini meliputi power supply (PS), PC, USB to TTL, module sensor IR tipe FC-51, driver L298N, dan LCD 16x2. Diagram blok perangkat keras sistem pemilah nanas otomatis seperti pada Gambar 1.

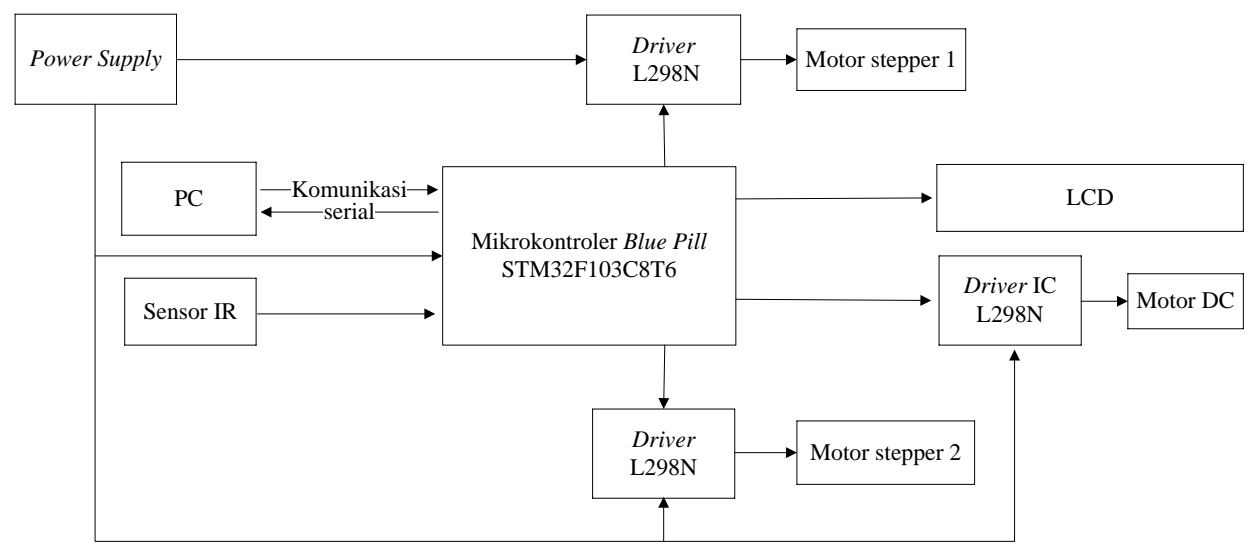

Gambar 1. Diagram blok sistem pemilah nanas

PS berfungsi untuk mensuplai tegangan motor DC dan motor stepper. PC berfungsi untuk mengirimkan data indeks kematangan nanas dalam bentuk kode karakter pada serial monitor Arduino IDE ke mikrokontroler melalui komunikasi serial menggunakan perangkat USB to TTL. Sensor IR berfungsi untuk mendeteksi nanas sebagai indikator motor stepper pemilah nanas. Driver motor IC L298N merupakan IC driver penggerak motor yang berfungsi mengatur kecepatan dan arah putaran pada motor DC, serta jumlah langkah pada motor stepper. LCD 16x2 digunakan untuk menampilkan hasil klasifikasi nanas berupa data indeks dan status kematangan nanas pada sistem pemilah nanas. Komponen tersebut dirangkai secara keseluruhan menjadi sistem unit kontrol otomatis seperti pada Gambar 2. 


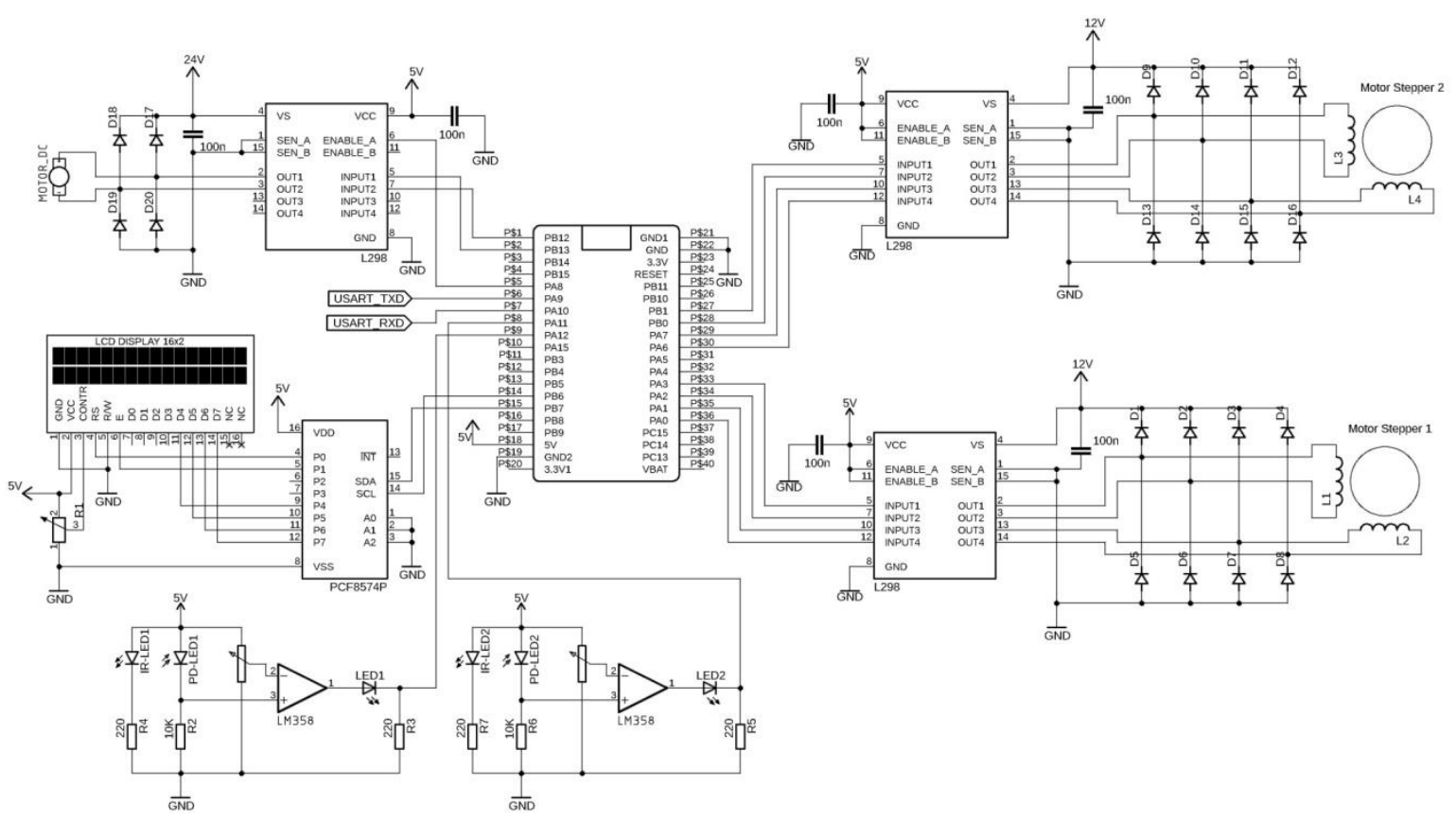

Gambar 2. Rangkaian sistem secara keseluruhan

a. Rangkaian sensor IR. Rangkaian sensor IR dalam module FC-51 yang dibuat menggunakan IC opamp LM358. Pada rangkaian tersebut terdapat sebuah transmitter infrared dan receiver potodioda sebagai input yang masuk ke IC LM358. IC ini berfungsi sebagai sebagai komparator tegangan untuk membandingkan tegangan masukan dari sensor potodioda dengan tegangan masukan dari potensiometer. Jika tegangan masukan pada $+\mathrm{V}$ lebih besar dari tegangan $-\mathrm{V}$, maka keluarannya berupa sinyal HIGH atau berlogika "1" dan menyalakan led sebagai indikator tidak adanya objek. Tetapi, jika tegangan masukan pada $+\mathrm{V}$ lebih rendah dari tegangan $-\mathrm{V}$, maka keluarannya berupa sinyal LOW atau berlogika "O" dan led tidak menyala yang berarti mendeteksi adanya objek.

b. Rangkaian Driver Motor L298N. Pengendalian gerak motor DC dan motor stepper dibantu menggunakan driver motor IC L298N. Pada driver motor terdiri dari rangkaian IC L298N yang ditambahkan rangkaian pendukung berupa dioda dan rangkaian regulator tegangan. Dioda $1 \mathrm{~N}-4007$ berfungsi sebagai proteksi terhadap induksi yang diakibatkan oleh perubahan putaran motor secara tiba-tiba. Sedangkan rangkaian regulator untuk mengatur tegangan yang berasal dari catu daya. Pada IC L298N terdapat 4 buah pin input, 2 buah pin enable dan 4 buah pin output. Pin input 1 dan 2 digunakan untuk mengontrol motor 1 yang dan pin input 3 dan 4 digunakan untuk mengontrol motor 2. Kombinasi ini berlaku untuk mengontrol motor DC yang memiliki 2 buah terminal. Sedangkan pada rangkaian motor stepper jenis bipolar yang terdiri dari 4 kabel dan 2 kumparan. Kumparan 1 untuk kabel 1 dan 2 dihubungkan ke input 1 dan 2 driver L298N, kumparan 2 untuk kabel 3 dan 4 dihubungkan ke input 3 dan 4 pada driver L298N. Sehingga untuk menggerakkan 1 motor stepper membutuhkan 1 buah driver.

c. Rangkaian LCD 16x2. Rangkaian LCD 16x2 dilengkapi dengan module komunikasi I2C (interintergrated circuit) yang hanya menggunakan 2 saluran komunikasi yaitu SCL (serial clock) dan SDA (serial data). Penggunaan module ini untuk lebih mudah menampilkan data pada LCD. Pengiriman data ini dilakukan melalui komunikasi serial USART (universal synchronous Asynchronous Receiver Transmitter) yang digunakan pada port serial atau terminal USB (universal serial bus) komputer ${ }^{9}$.

\subsection{Prinsip Kerja Sistem}

Prinsip kerja pada purwarupa pemilah nanas meliputi sistem konveyor dan pengendalian motor stepper untuk pemilah nanas dijelaskan pada diagram alir seperti Gambar 3. 
Desy F T, Surtono A, Supriyanto A, dan Junaidi, 2020, Rancang Purwarupa Pemilah Nanas Berdasarkan Tingkat Kematangan Menggunakan Mikrokontroler Blue Pill STM32F103C8T6, Jurnal of Energy, Material, and Instrumentation Technology, Vol. 1 No. 3, 2020

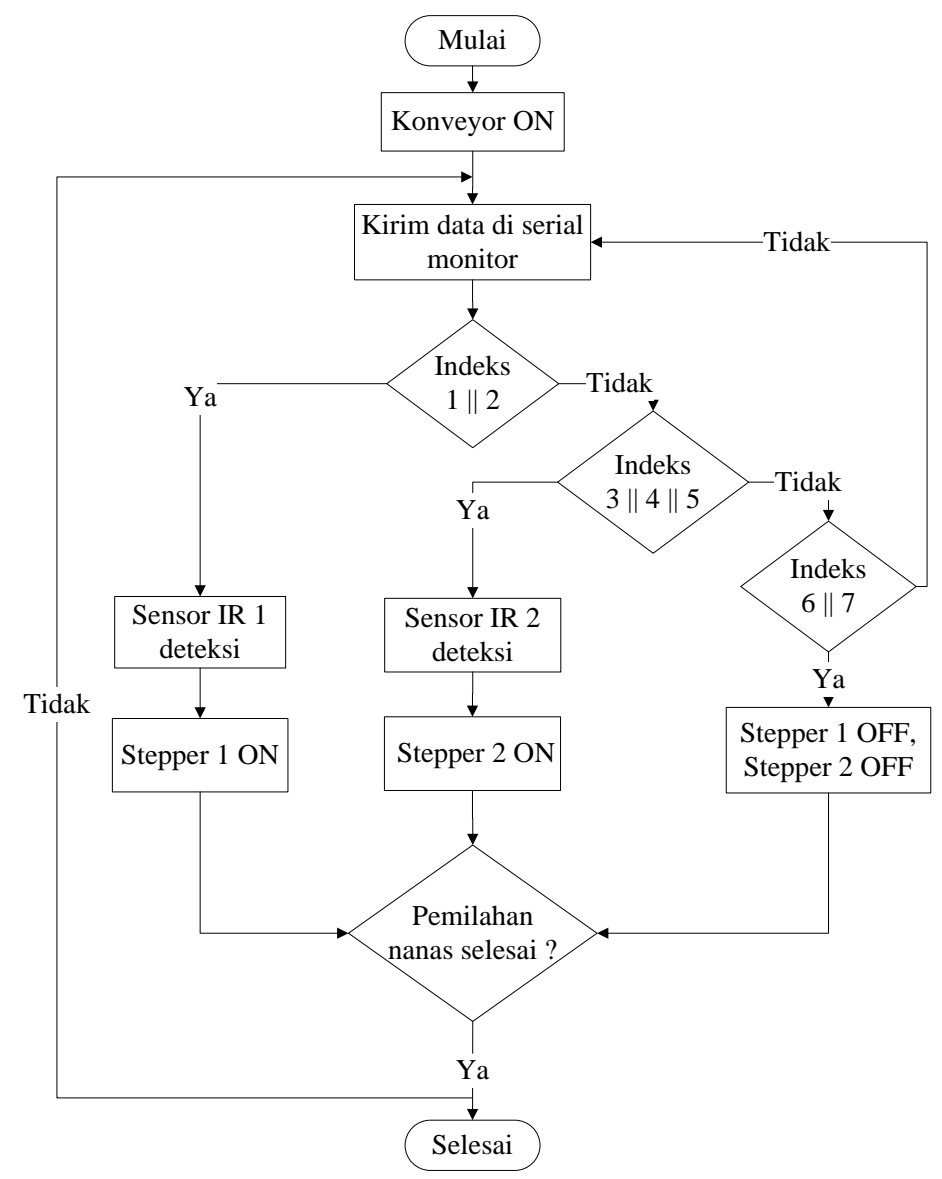

Gambar 3. Diagram alir sistem pemilah nanas

Proses pemilahan nanas dimulai dengan keadaan awal semua sistem mekanik menyala yaitu konveyor dalam kondisi ON. Pengiriman data serial indeks kematangan nanas oleh PC dikirimkan ke mikrokontroler. Data yang dikirimkan dalam format karakter berupa bilangan bulat 1, 2, 3, 4, 5, 6, dan 7, kemudin data akan disimpan pada memori mikrokontroler. Hasil klasifikasi yang dikirimkan berupa indeks 1 atau 2, maka sensor IR1 akan aktif mendeteksi nanas dan motor stepper 1 akan menggerakkan papan pemilah nanas mentah. Untuk hasil klasifikasi indeks 3 atau 4 atau 5, maka sensor IR2 akan aktif mendeteksi nanas dan motor stepper 2 akan menggerakkan papan pemilah nanas matang. Sedangkan hasil klasifikasi indeks 6 atau 7, maka kedua sensor IR dan motor stepper akan mati lalu nanas sangat matang akan diteruskan oleh sabuk konveyor menuju wadah penampungan.

\subsection{Pengujian dan Pengambilan Data}

Pengujian sistem dilakukan untuk mengetahui tingkat keberhasilan dari purwarupa yang dibuat. Pengujian ini dilakukan dengan cara mengukur arus dan tegangan motor DC menggunakan multimeter. Kemudian, pengujian keseluruhan sistem dilakukan pada purwarupa pemilah nanas untuk mengetahui kesesuaian program perangkat lunak terhadap sistem pemilah nanas. Pengambilan data dilakukan dengan cara menjalankan seluruh sistem untuk menentukan daya dan tegangan motor DC, respon waktu motor stepper terhadap kecepatan konveyor sabuk, serta ketepatan papan pemilah terhadap klasifikasi nanas. Besar daya motor DC dapat ditentukan menggunakan Persamaan 5:

$$
P=V I
$$

dengan $P$ merupakan daya listrik motor (watt), $V$ adalah tegangan motor DC (V), dan $I$ adalah kuat arus motor DC (A). Kemudian, untuk mendapatkan nilai akurasi papan pemilah terhadap klasifikasi nanas dapat dihitung menggunakan Persamaan 6: 


$$
\begin{aligned}
& \text { Akurasi pemilah } 1(\%)=\frac{n_{p}-\sum n_{2,3}}{n_{p}} \times 100 \% \\
& \text { Akurasi pemilah } 2(\%)=\frac{n_{p}-\sum n_{l, 3}}{n_{p}} \times 100 \% \\
& \text { Akurasi pemilah } 3(\%)=\frac{n_{p}-\sum n_{t, 2}}{n_{p}} \times 100 \%
\end{aligned}
$$

di mana $n_{1,2,3}$ merupakan jumlah pemilah 1,2 , dan 3 , dan $n_{p}$ adalah jumlah pengulangan (5 kali).

\section{Hasil dan Pembahasan}

\subsection{Realisasi Alat}

Purwarupa pemilah nanas secara otomatis berdasarkan tingkat kematangan dengan sistem konveyor sabuk menggunakan mikrokontroler Blue Pill STM32F103C8T6 seperti pada Gambar 4.

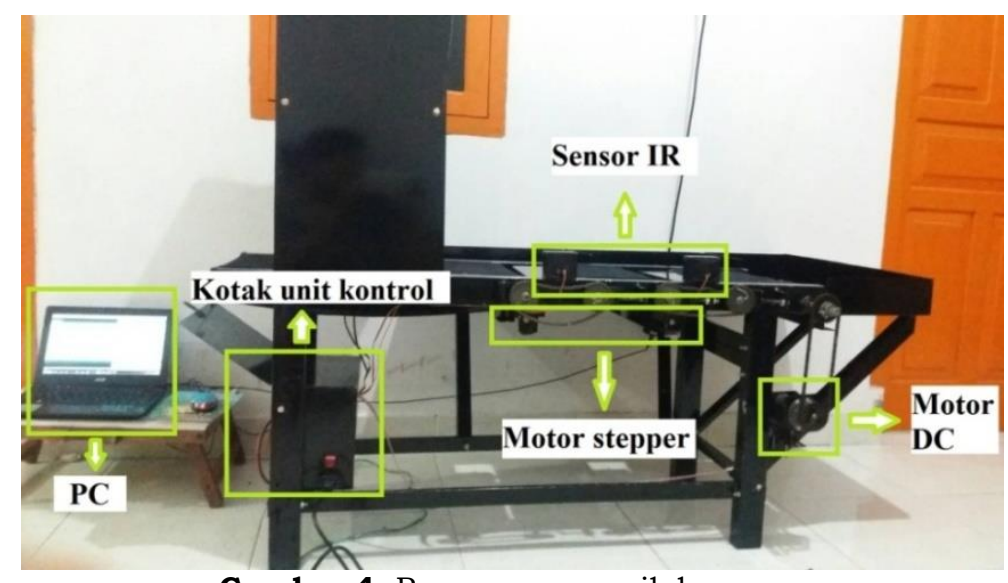

Gambar 4. Purwarupa pemilah nanas

Alat pemilah nanas dirancang dengan sistem mekanik berupa konveyor sabuk dan sistem kontrol pemilah nanas otomatis. Dimensi purwarupa pemilah nanas yang telah terealisasi memliki panjang $150 \mathrm{~cm}$, lebar $65 \mathrm{~cm}$, dan tinggi $110 \mathrm{~cm}$ dirancang mengunakan plat aluminium, pipa PVC, besi siku dan besi hollow $6 \times 4 \mathrm{~cm}$. Sabuk konveyor pada sistem ini terpisah menjadi 3 bagian yang terhubung menggunakan transmisi rantai dan roda gigi. Jarak pengangkutan tiap bagian sabuk yaitu sabuk pertama sebesar $60 \mathrm{~cm}$, sabuk kedua dan sabuk ketiga sebesar $20 \mathrm{~cm}$. Jenis sabuk yang digunakan synthetic fabric berbahan denim dengan lebar $28 \mathrm{~cm}$ dan tebal 0,9 mm. Diameter rol penggerak sabuk konveyor yaitu $60 \mathrm{~mm}$ atau $0,06 \mathrm{~m}$. Parameter penggerak konveyor sabuk ditunjukkan pada Tabel 1.

Tabel 1. Parameter perencanaan sistem mekanik konveyor sabuk

\begin{tabular}{cll}
\hline No & \multicolumn{1}{c}{ Parameter } & \multicolumn{1}{c}{ Hasil } \\
\hline 1 & Kecepatan putar motor penggerak & $80,2 \mathrm{rpm}$ \\
2 & Torsi motor penggerak & $2 \mathrm{Nm}$ \\
3 & Kapasitas angkut & $367,35 \mathrm{tumpahan} / \mathrm{jam}$ \\
4 & Kapasitas angkut maksimum & $367,35 \mathrm{~kg} / \mathrm{jam}$ \\
5 & Kecepatan konveyor & $25,17 \mathrm{~cm} / \mathrm{s}$ \\
6 & Daya yang dibutuhkan konveyor sabuk & $4,19 \mathrm{Watt}$ \\
\hline
\end{tabular}

\subsection{Sistem Pengontrolan Purwarupa Pemilah Nanas}


Desy F T, Surtono A, Supriyanto A, dan Junaidi, 2020, Rancang Purwarupa Pemilah Nanas Berdasarkan Tingkat Kematangan Menggunakan Mikrokontroler Blue Pill STM32F103C8T6, Jurnal of Energy, Material, and Instrumentation Technology, Vol. 1 No. 3, 2020

Purwarupa pemilah nanas secara otomatis dikendalikan menggunakan mikrokontroler Blue Pill STM32F103C8T6. Pengontrolan sistem oleh mikrokontroler yaitu melakukan proses pemilahan nanas dengan mengontrol kerja motor stepper menggerakkan papan pemilah dan kerja motor DC menggerakkan konveyor sabuk. Pengendalian motor stepper dilakukan berdasarkan data serial dalam format karakter berupa bilangan bulat 1, 2, 3, 4, 5, 6, dan 7 yang dikirimkan oleh PC, dan kondisi sensor IR pendeteksi adanya objek nanas yang akan dipilah dijelaskan pada Tabel 2.

Tabel 2. Pengendalian motor stepper pemilah nanas

\begin{tabular}{ccccc}
\hline $\begin{array}{c}\text { Data Indeks } \\
\text { Kematangan }\end{array}$ & \multicolumn{2}{c}{ Kondisi Sensor IR } & \multicolumn{2}{c}{ Kondisi Motor Stepper } \\
\cline { 2 - 5 } IR 1 & IR 2 & Stepper 1 & Stepper 2 \\
\hline 1 & 0 & 1 & ON & OFF \\
2 & 0 & 1 & ON & OFF \\
3 & 1 & 0 & OFF & ON \\
4 & 1 & 0 & OFF & ON \\
5 & 1 & 0 & OFF & ON \\
6 & 1 & 1 & OFF & OFF \\
7 & 1 & 1 & OFF & OFF \\
\hline
\end{tabular}

\subsection{Daya dan Tegangan Motor DC}

Daya dan tegangan listrik motor DC diukur pada saat kondisi idle dan aktif. Kondisi idle merupakan kondisi dimana motor menggerakkan konveyor tanpa adanya beban, sedangkan kondisi aktif yaitu kondisi dimana motor bekerja saat konveyor mengangkut beban. Pengukuran tegangan masuk ( $\left.V_{\text {in }}\right)$ dan tegangan keluar $\left(V_{\text {out }}\right)$ serta besarnya arus (I) yang bekerja pada motor DC menggunakan alat multimeter untuk mengetahui besar daya yang dibutuhkan motor DC. Hasil pengujian dapat disajikan pada Tabel 3.

Tabel 3. Daya dan tegangan motor DC penggerak konveyor sabuk

\begin{tabular}{cccccc}
\hline \multirow{2}{*}{ No } & \multirow{2}{*}{ Kondisi } & \multicolumn{2}{c}{ Tegangan } & \multirow{2}{*}{ (A) } & \multirow{2}{*}{$\boldsymbol{P}$ (watt) } \\
\cline { 3 - 4 } & & $\boldsymbol{V}_{\text {in }}(\mathbf{V})$ & $\boldsymbol{V}_{\text {out }}(\mathbf{V})$ & & \\
\hline 1 & Idle & 24,20 & 24,19 & 6,04 & 0,25 \\
2 & Aktif & 24,18 & 23,84 & 8,82 & 0,37 \\
\hline
\end{tabular}

Pada Tabel 3 diperoleh tegangan keluar $\left(V_{\text {out }}\right)$ pada kondisi idle motor hanya mengalami penurunan tegangan sebesar $0,01 \mathrm{~V}$, sedangkan pada kondisi motor aktif mengalami penurunan tegangan mencapai 0,34 V. Penurunan tegangan ini terjadi karena adanya beban nanas sehingga konsumsi daya yang dibutuhkan oleh motor DC untuk menggerakkan konveyor bertambah besar, dengan daya yang dikeluarkan oleh motor DC saat menggerakkan konveyor dalam kondisi aktif sebesar 8,82 watt.

\subsection{Laju Pengangkutan Konveyor Sabuk}

Laju konveyor ini merupakan kecepetan rata-rata pengangkutan terhadap beban buah nanas. Untuk mengetahui laju konveyor dengan massa buah nanas maksimum yang mampu diangkut oleh konveyor yaitu dilakukan pengujian menggunakan sampel 0,5; 1,0; dan 1,5 $\mathrm{kg}$. Konveyor mampu menggangkut beban dengan massa 0,5 dan $1,0 \mathrm{~kg}$ dengan kecepatan stabil, sedangkan pada sampel nanas massa $1,5 \mathrm{~kg}$ konveyor seketika langsung berhenti dan tidak berjalan. Dengan demikian, massa maksimum yang mampu diangkut oleh konveyor pada purwarupa pemilah nanas yaitu sebesar $1,0 \mathrm{~kg}$. Dari hasil pengujian dapat ditentukan besar kecepatan rata-rata pengangkutan beban buah nanas yang diangkut. Jarak tempuh pengakutan nanas yaitu sepanjang konveyor sabuk $120 \mathrm{~cm}$, dengan waktu tempuh tiap beban nanas dihitung menggunakan stopwatch. Hasil pengujian dan pengambilan data dapat dilihat pada Gambar 5. 


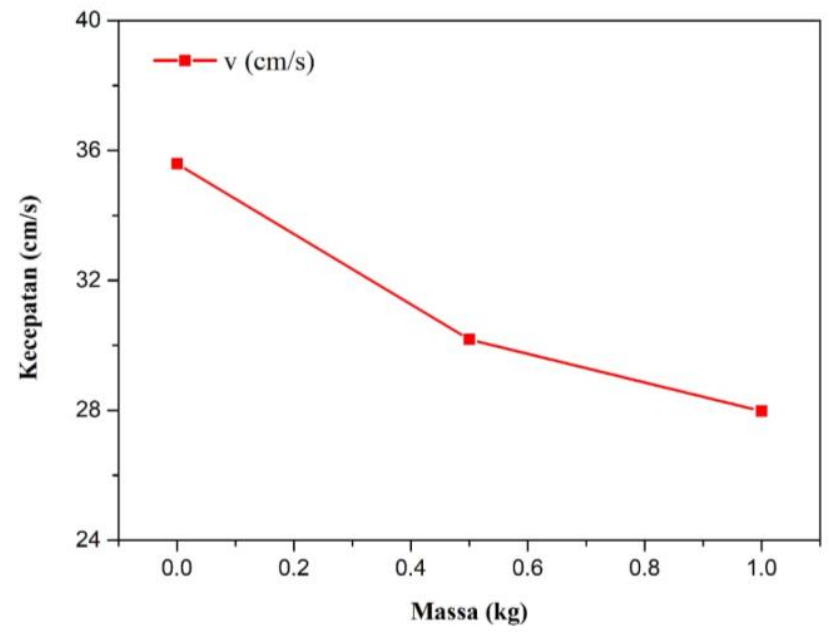

Gambar 5. Grafik hubungan kecepatan pengangkutan terhadap beban

Gambar 5 merupakan grafik hubungan antara kecepatan pengangkutan dengan beban yang menunjukkan bahwa kecepatan pengangkutan konveyor sabuk semakin kecil dengan bertambahnya beban pengangkutan. Hal ini menunjukkan bahwa kecepatan berbanding terbalik dengan massa yaitu semakin besar beban benda maka kecepatan benda akan semakin kecil (Sirait, 2018). Pada saat konveyor sabuk bergerak tanpa beban diperoleh kecepatan rata-rata sebesar 35,59 cm/s, sedangkan pada saat diberikan beban angkut buah nanas dengan massa 0,5 dan 1,0 kg diperoleh masingmasing kecepatan rata-rata pengangkutan buah nanas sebesar 30,18 dan $27,98 \mathrm{~cm} / \mathrm{s}$.

\subsection{Respon Waktu Pemilah Nanas}

Respon waktu pada setiap papan pemilah terhadap kecepatan konveyor sabuk pada tiap klasifikasi kematangan nanas. Jarak tempuh mencapai papan pemilah 1 nanas mentah yaitu $60 \mathrm{~cm}$, jarak tempuh papan pemilah 2 nanas matang yaitu $80 \mathrm{~cm}$, dan jarak tempuh pemilah 3 nanas sangat matang yaitu $120 \mathrm{~cm}$. Hasil pengujian respon waktu papan pemilah dapat dilihat pada Gambar 6 .

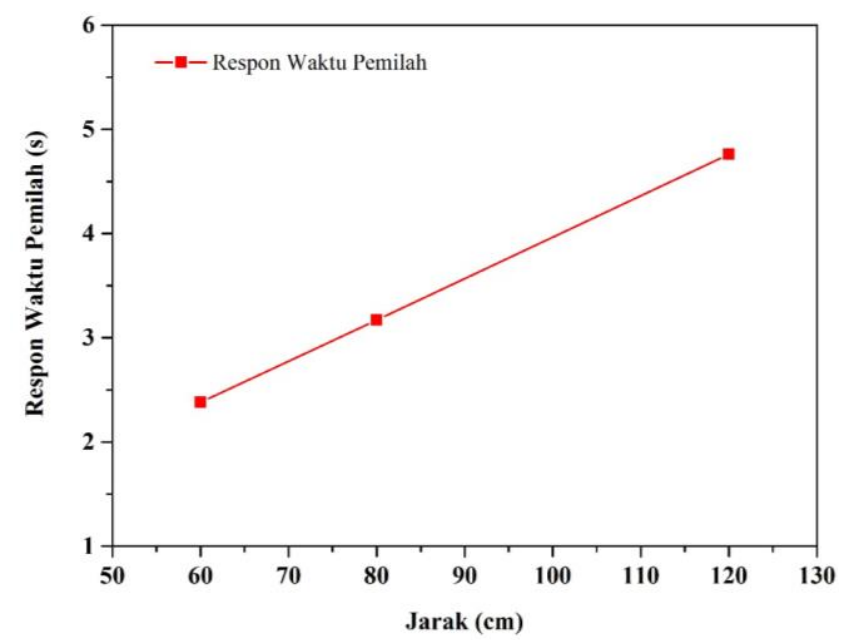

Gambar 6. Grafik hubungan respon waktu dengan jarak tempuh pemilah

Gambar 6 yang merupakan grafik hubungan antara respon waktu dengan jarak tempuh pemilah nanas menunjukkan bahwa respon waktu pada setiap pemilahan semakin lama ketika jarak tempuh pengangkutan buah nanas semakin jauh. Hal ini menunjukka bahwa jarak dan waktu mempunyai nilai yang berbanding lurus. Jika jarak pengangkutan diperbesar, maka nilai respon waktu semakin besar (Prihatini dkk., 2017). Respon waktu papan pemilah ini berdasarkan pada waktu tempuh buah nanas mencapai papan pemilahan dengan kecepatan konveyor sabuk sebesar $25,17 \mathrm{~cm} / \mathrm{s}$.

\subsection{Ketepatan Pemilahan Klasifikasi Kematangan Nanas}

Untuk mengetahui respon papan pemilah dan ketepatan pemilahan terhadap klasifikasi kematangan nanas dilakukan pengujian menggunakan 5 sampel buah nanas dan mengirimkan data 
Desy F T, Surtono A, Supriyanto A, dan Junaidi, 2020, Rancang Purwarupa Pemilah Nanas Berdasarkan Tingkat Kematangan Menggunakan Mikrokontroler Blue Pill STM32F103C8T6, Jurnal of Energy, Material, and Instrumentation Technology, Vol. 1 No. 3, 2020

serial indeks kematangan nanas melalui komunikasi serial antara PC dengan mikrokontroler. Data serial 1 dan 2 untuk menggerakkan motor stepper pada papan pemilah 1, data serial 3, 4, dan 5 untuk menggerakkan motor stepper pada papan pemilah 2, sedangkan data serial 6 dan 7 tidak menggerakkan motor stepper. Tingkat akurasi pemilahan klasifikasi kematangan buah nanas disajikan pada Tabel 4.

Tabel 4. Ketepatan pemilahan klasifikasi kematangan nanas

\begin{tabular}{|c|c|c|c|c|c|c|}
\hline \multirow{2}{*}{$\begin{array}{c}\text { Data } \\
\text { Indeks }\end{array}$} & \multirow{2}{*}{$\begin{array}{l}\text { Klasifikasi } \\
\text { Kematangan }\end{array}$} & \multirow{2}{*}{ Pengulangan } & \multicolumn{3}{|c|}{ Pemilah } & \multirow{2}{*}{ Akurasi } \\
\hline & & & 1 & 2 & 3 & \\
\hline 1 & Mentah & 5 kali & 5 & 0 & 0 & $100 \%$ \\
\hline 2 & Mentah & 5 kali & 4 & 0 & 1 & $80 \%$ \\
\hline \multicolumn{6}{|c|}{ Rata-rata pemilah 1} & $90 \%$ \\
\hline 3 & Matang & 5 kali & 0 & 5 & 0 & $100 \%$ \\
\hline 4 & Matang & 5 kali & 0 & 5 & 0 & $100 \%$ \\
\hline 5 & Matang & 5 kali & 0 & 4 & 1 & $80 \%$ \\
\hline \multicolumn{6}{|c|}{ Rata-rata pemilah 2} & $93,33 \%$ \\
\hline 6 & Sangat Matang & 5 kali & 0 & 0 & 5 & $100 \%$ \\
\hline 7 & Sangat Matang & 5 kali & 0 & 0 & 5 & $100 \%$ \\
\hline \multicolumn{6}{|c|}{ Rata-rata pemilah 3} & $100 \%$ \\
\hline
\end{tabular}

Pada Tabel 4 menunjukkan akurasi pemilahan lebih dari 90\%, sehingga dapat dikatakan sangat baik pada proses pemilahan menggunakan sistem konveyor sabuk. Pemilah 1 klasifikasi nanas mentah diperoleh akurasi pemilahan rata-rata sebesar 93,33\%, pemilah 2 klasifikasi nanas matang sebesar $90 \%$, dan pemilah 3 klasifikasi nanas sangat matang sebesar $100 \%$.

\section{Kesimpulan}

Berdasarkan hasil pengujian dan pembahasan yang telah dilakukan dapat disimpulkan bahwa purwarupa pemilah nanas berdasarkan tingkat kematangan secara otomatis dapat direalisasikan menggunakan mikrokontroler Blue Pill STM32F103C8T6. Alat ini dibuat menggunakan sistem konveyor sabuk dan mampu mengangkut beban maksimum buah nanas sebesar 1,0 kg dengan kecepatan pengangkutan sebesar $27,98 \mathrm{~cm} / \mathrm{s}$. Pemilahan nanas terhadap klasifikasi kematangan nanas yang dilakukan menggunakan motor stepper bekerja sangat baik dengan akurasi lebih dari $90 \%$.

\section{Ucapan Terimakasih}

Penulis mengucapkan terima kasih kepada Kepala Laboratorium Elektronika Dasar dan Instrumentasi Jurusan Fisika FMIPA Universitas Lampung yang telah membantu dalam penyelesaian penelitian ini.

\section{Daftar Pustaka}

Kementerian Pertanian. 2015. Rencana Strategis Kementerian Pertanian Tahun 2015-2019. Kementerian Pertanian RI. Jakarta.

2016. Outlook Nenas. Pusat Data dan Sistem Informasi Pertanian. Jakarta.

Badan Pusat Statistik. 2017. Statistik Tanaman Buah-Buahan dan Sayuran Tahunan Indonesia. Badan Pusat Statistik. Jakarta.

Tamam, M. T., Taufiq, A. J., dan Dwiono, W. 2018. Perencanaan dan Pembuatan Prototipe Sistem Sortir Buah Jeruk. TECHNO. Vol. 19, No. 1. Hal. 1-6. 
Shamsudin, R., Daud, W. R. N., Takrif, M. S., dan Hassan, O. 2009. Chemical Compositions and Thermal Properties of the Josapine Variety of Pineapple Friut (Ananas Comosus L.) in Different Storage Systems. Journal of Food and Process Engineering. Vol. 34, No. 5. Hal. 1558-1572.

Bakar, B. H. A., Ishak, A. J., Shamsuddin, R., dan Hassan, W. Z. W. 2013. Ripeness Level Classification For Pineapple Using RGB and HIS Colour Maps. Journal of Theoretical and Applied Information Technology. Vol. 57, No. 3. Hal. 587-593.

Uicker, J. J., Pennock, G. R., dan Shigley, J. E. 2016. Theory of Machines and Mechanisms, Fifth Edition. Oxford University Press. United Stated of America.

Khurmi, R. S dan Gupta, J. K. 2005. A Text Book of Machine Design. Eurasia Publishing House (Pvt) Ltd. New Delhi.

Sirait, R. 2018. Pengaruh Massa Terhadap Kecepatan dan Percepatan Berdasarkan Hukum II Newton Menggunakan Linier Air Track. FISITEK: Jurnal Ilmu Fisika dan Teknologi. Vol. 2, No. 2. Hal. 1117.

Triansah, A. 2017. Authentifikasi Login User pada Perangkat Lunak Menggunakan Arduino Uno dan Enkripsi AES 256. Expert-Jurnal Management Sistem Informasi dan Teknologi. Vol. 7, No. 2 . Hal. 90-95.

Prihatini, S., Handayani, W., dan Agustina, R. D. 2017. Identifikasi Faktor Perpindahan Terhadap Waktu yang Berpengaruh pada Kinematika Gerak Lurus Beraturan (GLB) dan Gerak Lurus Berubah Beraturan (GLBB). JoTaLP: Journal of Teaching and Learning Physics. Vol. 2, No. 2. Hal. 13-20. 